\title{
Vitamin D and atherosclerosis
}

\author{
Vesna Lazić', \\ Biljana Mijović́, \\ Miloš Maksimović ${ }^{3}$, \\ Olivera Rašević, \\ Maida Mulićs, \\ Maja Vuković ${ }^{2}$
}

${ }^{1} \mathrm{PHI}$ Public Health Institute of the Republic of Srpska, Regional Center Zvornik, The Republic of Srpska, Bosnia and Herzegovina 2University of East Sarajevo, Faculty of Medicine Foca, The Republic of Srpska, Bosnia and Herzegovina

${ }^{3}$ University of Belgrade, Faculty of Medicine, Belgrade, Institute of Hygiene with Medical Ecology, Serbia ${ }^{4}$ University Hospital Foca, The Republic of Srpska, Bosnia and Herzegovina ${ }^{5}$ Public Health Institute Tuzla's Canton, Bosnia and Herzegovina

Primljen - Received: 12/02/2021

Prihvaćen - Accepted: 01/04/2021

\section{Corresponding author:}

Vesna Lazić, MD

Svetog Save 37/a, 75400 Zvornik

lazicdrvesna@hotmail.com

Copyright: @2021 Vesna Lazić et all. This is an Open Access article distributed under the terms of the Creative Commons Attribution 4.0 International (CC BY 4.0) license.

\section{Summary}

Cardiovascular diseases rank first on the mortality list globally or $31 \%$. The basic measure of prevention in accordance with the recommendations of the World Health Organization is a change in risk lifestyle in terms of diet, physical activity, tobacco and alcohol consumption. Vitamin D was previously recognized as a regulator of calcium and phosphorus ratio, bone remodeling or the main controller of skeletal pathophysiology. However, vitamin D enjoys great interest in clinical and epidemiological research in terms of its possible impact on reducing the risk of cardiovascular diseases. Among other things, vitamin D deficiency is associated with an increased risk of endothelial dysfunction. Although the deficiency has been identified as a risk marker for cardiovascular diseases, the mechanism of action of vitamin D on the path from endothelial dysfunction to cardiovascular diseases has not been fully revealed. The findings in this segment of activity of vitamin D would be significant in terms of reducing morbidity and mortality from cardiovascular diseases.

Key words: vitamin D, endothelial dysfunction, atherosclerosis, cardiovascular diseases, mortality

\section{Introduction}

Vitamin D in the body is not dependent exclusively on nutritional sources, which somewhat refutes its name "vitamin", because the way it originates in the body, "hormone" would be more appropriate name. According to its chemical structure, it belongs to the group of steroids [1]. Whether it originates from nutritional food sources of plant (ergocalciferol, D2) or animal origin (cholecalciferol, D3) or is formed under the reaction of ultraviolet B (UVB) rays on the 
skin from 7-dehydrocholesterol (D3), in order to become active, double hydroxylation is necessary [1]. The first hydroxylation of vitamin $\mathrm{D}$ takes place in the liver through the enzyme D3-25, hydroxylase. The second hydroxylation takes place via the enzyme D3-1a-hydroxylase (primary kidney cells). After double hydroxylation, the active form of vitamin $\mathrm{D}$ or calcitriol was obtained. There is another active form of vitamin $\mathrm{D}$ that is formed by dihydroxylation in the kidneys (positions 24 and 25), known as 24,25-dihydroxycholecalciferol [1,2]. Vitamin $\mathrm{D}$ ( $\mathrm{D}$ represents $\mathrm{D}_{2^{\prime}}$ or $\mathrm{D}_{3^{\prime}}$ or both) that is ingested is incorporated into chylomicrons, which are absorbed into the lymphatic system, enter the venous blood and interact with its nuclear vitamin $\mathrm{D}$ receptor in the small intestine, kidneys, and other tissues [2]. It should be noted that D2 and D3 are used for food fortification and in vitamin D supplements [2].

\section{Epidemiological data}

Clinical and epidemiological studies have linked vitamin D deficiency to non-skeletal disorders. Based on epidemiological studies a wide range of non-skeletal diseases have been linked to vitamin D such as cardiovascular, malignant and immune diseases, then diabetes mellitus and multiple sclerosis $[3,4,5]$.

The role of vitamin $\mathrm{D}$ in CVD received an epilogue at a time when scientists came up with statistics that the prevalence of ischemic heart disease and hypertension is higher in countries that have fewer sunny days a year. Similar studies have shown that the incidence of cardiovascular adverse events is more common in winter [6].

Also, in survey from 2013 to 2015 based on measuring the concentration of $25(\mathrm{OH})$ $\mathrm{D}$ in 1,078 patients and basic information, scientists concluded that prevalence of CVD was $59.28 \%$ in the vitamin D deficient group [7]. Researchers of Framingham study have proved that concentrations of $25(\mathrm{OH}) \mathrm{D}<15$ $\mathrm{ng} / \mathrm{ml}$ were associated with $60 \%$ increased risk of a future cardiovascular event. The highest risk was evident in individuals with hypertension [8]. A study in Finland that included 6,219 men and women without cardiovascular diseases has proved that the largest quantile of $25(\mathrm{OH}) \mathrm{D}$ had $24 \%$ lower risk for CVD [9].

In the Vindicate study which included 229 patients (179 men) with chronic HF due to LVSD and vitamin D deficiency (cholecalciferol $<50 \mathrm{nmol} / 1[<20 \mathrm{ng} / \mathrm{ml}]$ ) participants were allocated to 1 year of vitamin D3 supplementation $(4,000 \mathrm{IU}$ [100 $\mu \mathrm{g}$ ] daily) or matching non-calcium-based placebo [10]. Authors have concluded that the one year of $100 \mu \mathrm{g}$ daily vitamin D3 supplementation does not improve 6-min walk distance but has beneficial effects on LV structure and function in patients on contemporary optimal medical therapy. Further studies are necessary to determine whether these translate to improvements in outcomes [10].

Houghton and Lew suggested that there was an increased risk for hypercalcemia related to over supplementation with vitamin D. They presented the hypervitaminosis D-induced hypercalcaemia in an individual taking 50,000 IU of vitamin D supplement daily for several months due to vitamin D deficiency. Over supplementation with vitamin D caused hypercalcemia $(>2.6 \mathrm{mmol} / \mathrm{L})$ with reported mild chronic abdominal pain with constipation, nausea, vomiting, hypertension and tachycardia at the first (of seven) hospital admission. Due to persistent symptomatic hypercalcemia (liposolubility of vitamin D), patient required six more admissions. Authors suggested that the increased awareness of vitamin D deficiency and accessibility of vitamin D supplements may increase frequency of hypervitaminosis D-induced hypercalcemia [11].

The ARIC study included four cities in the United States of America and was conducted as a prospective cohort study with over 15,000 respondents for a period of 33 years of 
follow-up. Namely, the design of the study is such that the subjects were visited five times during the stated period, and that the variables necessary for the study were collected at that time. Serum samples were collected during the second visit and stored at $-70^{\circ} \mathrm{C}$, analyzed by liquid chromatography for the presence of 25(OH)D during 2012 and 2013. After statistical analysis, the researchers concluded that lower HDL concentrations and higher TGL/HDL - $\mathrm{C}$ ratio were recorded in participants with a deficiency of $25(\mathrm{OH}) \mathrm{D}$ ( $<20 \mathrm{ng} / \mathrm{ml}$ ) compared to participants with an optimal concentration of $25(\mathrm{OH}) \mathrm{D}(\geq 30 \mathrm{ng} /$ $\mathrm{ml}$ ) with CI of $95 \%$ [12]. A study conducted in the United States indicated that $83.5 \%$ of patients ( $\mathrm{n}=314)$ admitted to hospital for acute myocardial infarction had a low serum concentration of $25(\mathrm{OH}) \mathrm{D}(25(\mathrm{OH}) \mathrm{D}<75 \mathrm{nmol} / \mathrm{l})$ [13]. The risk of myocardial infarction and stroke is significantly higher in people with vitamin D deficiency showed the European Prospective Investigation into Cancer and Nutrition (EPIC) [14].

In population-based cohort study - Roterdam study, authors found an association between vitamin $\mathrm{D}$ and prevalent stroke. Out of 9,680 participants, 339 had a history of stroke at baseline. Serum 25-hydroxyvitamin D concentration was associated with prevalent stroke (OR: 1.31; 95\% CI, 1.14-1.51). Only severe vitamin $\mathrm{D}$ deficiency was associated with incident stroke (hazard ratio, 1.25; 95\% CI, 1.05-1.50) [15].

During a clinical study in Poland involving 266 men and 144 women aged $65.4 \pm 10.8$, the researchers concluded that coronary artery lesions detected by coronary angiography were more common in patients with lower concentrations of $25(\mathrm{OH}) \mathrm{D}$. Also, they unequivocally proved that patients with acute coronary syndrome had a significantly lower concentration of $25(\mathrm{OH}) \mathrm{D}$ compared to patients with stable coronary disease [16].

A retrospective study conducted from 2004 to 2015, including patients with chest pain and patients who underwent angiography. The results indicated that patients with normal concentration of $25(\mathrm{OH}) \mathrm{D}$ had coronary arteries without damage compared to a patient with low concentration $(20-29.9$ $\mathrm{ng} / \mathrm{ml}$ ), or lack (> $20 \mathrm{ng} / \mathrm{ml}$ ) of $25(\mathrm{OH}) \mathrm{D}$ ( OR: 7, 95\% CI: $5.2-9.5, \mathrm{p}<0.0001)$. Also, patients with low concentration or lack of vitamin $\mathrm{D}$ metabolites show signs of obstructive coronary artery disease in $62 \%$ of cases $(n=624$, OR: $2.9,95 \%$ CI: $2.3-3.7, p<0.0001$ ), or $25 \%$ without signs of coronary artery obstruction $(n=249$, OR: 1.5, 95\% CI: $1.1-2, p=0.02)$ [17].

\section{The role of vitamin $\mathrm{D}$ in atherogenesis}

Morbidity and mortality from CVD have a great socio-economic impact and represent the greatest burden on health systems globally [18]. The role of vitamin D in CVD is not clear at this point. Recent decades of research have shown that vitamin $\mathrm{D}$ is associated with atherogenesis. The discovery of vitamin $\mathrm{D}$ receptors in other organs (gastrointestinal tract, parathyroid glands, thyroid glands, pituitary gland, central nervous system, immune system, respiratory system, connective tissue and myocardium) reveals possible roles of vitamin $\mathrm{D}[3,4,5]$. The most important are:

- increase in the concentration of nitric oxide in the endothelium,

- inhibition of platelet and leukocyte aggregation and adhesion,

- reduction of oxidative stress in the endothelium,

- influence on muscle tone of blood vessels,

- reduction in the release of vasoconstrictor substances,

- inhibits the release of proinflammatory cytokines,

- modulation of the immune response,

- inhibition of proliferation and migration of smooth muscle cells of blood vessels.

Endothelium is the largest regulator of 
vascular homeostasis, which is reflected in the effects of vasoconstriction, vasodilation, smooth muscle tissue proliferation, thrombogenesis, inflammation and fibrinolysis [19]. If vascular endothelial dysfunction occurs, atherosclerosis develops. Vascular endothelial cells show the expression of vitamin D receptors (VDRs), which may play a protective role in the preservation of endothelium through various mechanisms of action. Also, VDR in endothelial cells expresses the enzyme 1a-hydroxylase, which consequently hydroxylates circulating $25(\mathrm{OH}) \mathrm{D}$ to the active form of vitamin D (calcitriol) [20]. The next step in the action of vitamin D on the endothelium is to regulate the production and release of nitric oxide (NO) through direct transcription and consequent vasodilation. If there is a decrease in the serum concentration of vitamin $\mathrm{D}$, the consequence is a lower bioavailability of $\mathrm{NO}$ in the endothelium. In addition to the vasodilatory effect, NO plays a significant role in reducing platelet and leukocyte aggregation/ adhesion. Vitamin D has been shown to have a protective role on the endothelium. Namely, vitamin $\mathrm{D}$ successfully prevents the accumulation of superoxide in endothelial cells. An observational study $(\mathrm{n}=957)$ indicated that a low serum concentration of $25(\mathrm{OH}) \mathrm{D}$ was associated with an increased degree of inflammation, i.e. the concentration of IL-6 and CRP increased with a decrease in the concentration of the anti-inflammatory cytokine IL-10 [21]. Also, the low level of $25(\mathrm{OH}) \mathrm{D}$ in the circulation indicated a connection with the lipid profile of patients with diabetes, obesity and hypertension [22]. Namely, vitamin D limits the formation of foam cells and improves the transport of HDL, which indicates a possible protective mechanism [23].

There is evidence that vitamin D affects vascular tone depending on blood pressure. It is assumed that the mechanism of action is the reduction of endothelium-dependent contractions. The influx of $\mathrm{Ca}$ ions into endothelial cells causes the activation of the enzyme
Ca-dependent phospholipase A2 and then starts the reaction of conversion of phospholipids from the cell membrane into arachidonic acid metabolites - endothelial vasoconstriction factors. This reaction is catalyzed by cyclooxygenase (COX) enzymes or the conversion of arachidonic acid into endoperoxides, which are converted into prostaglandins and thromboxane A2 under the action of synthase enzymes. It is thought that in this reaction, vitamin D may lead to a reduction in the release of endothelial vasoconstriction factors by preventing an increase in concentration of Ca in endothelial cells [24]. Also, research has shown that vitamin D reduces the expression of the enzyme COX and increases the expression of 15-hydroprostaglandin dehydrogenase, which ultimately results in reduced COX secretion and inactivation of prostaglan$\operatorname{din}[25]$.

In the process of atherosclerosis, in addition to the endothelium, the cells of the smooth muscle of the blood vessels also play an important role. Namely, these cells participate in the production of the extracellular matrix, which represents the beginning of atherogenesis [26]. Smooth muscle cells also possess VDR, which expresses the enzyme 1a-hydroxylase. Vitamin D has an antiproliferative effect on smooth muscle cells by inhibiting the enzyme endothelium-dependent DNA synthase and cell proliferation, then the effect on elastogenesis and immunomodulation [27]. Physiological doses of vitamin $\mathrm{D}$ inhibit the release of proinflammatory cytokines, adhesion molecules and the proliferation of smooth muscle cells of the blood vessels, which results in the suppression of calcification of the intima and media of blood vessels [27].

If endothelial damage occurs, it triggers a series of immune reactions that lead to atherosclerosis. Inflammation also activates $\mathrm{T}$ helper lymphocytes, macrophages and other immune response cells, while endothelial lesions lead to cholesterol infiltration. T helper 
lymphocytes are primarily responsible for the proatherogenic response during endothelial inflammation by the production of cytokines (interleukin 2, interferon gamma, TNF alpha and beta, etc.) that cause macrophage activation. At the same time, $\mathrm{T}$ helper lymphocytes secrete interleukins that affect the production of antibodies by B lymphocytes, i.e. the immune response to inflammation [28].

Although the role of T helper lymphocytes in atherogenesis is unclear, there is evidence to suggest that their function is antiatherogenic due to the secretion of interferon gamma and certain cytokines [4]. There is evidence that vitamin $\mathrm{D}$ inhibits the proliferation of $\mathrm{T}$ lymphocytes and thus reduces the expression of interferon gamma and interlukin 2, which play a major role in the proatherogenic response. There is also evidence to suggest that vitamin $\mathrm{D}$ affects a stronger $\mathrm{T}$ helper lymphocyte response and has a direct effect on B lymphocyte regulation and antibody production. The result is an atheroprotective effect with stronger protection and reduced immune response to the inflammatory process $[29,30]$. However, it should be noted that the effects of vitamin D on B lymphocytes as an indirect consequence of its effect on $\mathrm{T}$ lymphocytes are mentioned earlier in the manuscript.

Studies have shown that vitamin D affects the reduction of the process of taking up oxidized LDL by monocytes and macrophages, which results in a reduction in the formation of foam cells. Vitamin D has a similar effect immediately, acting on TNFa, which also prevents the migration of monocytes and transformation into foam cells [31]. Also, vitamin $\mathrm{D}$ reduces the expression of adhesion molecules (vascular adhesion molecule 1 and matrix metalloproteinases 1) which prevent platelet aggregation [32].

Vitamin D also shows an indirect atheroprotective effect by acting on pancreatic $\beta$ cells, serum lipoproteins and the renin-angiotensin-aldosterone system (RAAS). Studies have shown that there is VDR on pancreatic $\beta$ cells and that it has a function in the normal insulin secretion when vitamin D is bound to VDR. There are indications that the serum concentration of vitamin $\mathrm{D}$ is directly linked to the pancreatic $\beta$ cells, causing better control of the serum concentration of glucose. Researchers searched the EMBASE, PUBMED and COCHRAINE databases, with the keywords glycosylated hemoglobin, serum vitamin D and blood sugar, and concluded that supplementation with reduced serum concentrations of vitamin $\mathrm{D}$ had a direct effect on reducing the markers of insulin resistance [33]. RAAS is the largest regulator of blood pressure in the body. The components RAAS, angiotensin II and aldosterone are associated with the pathogenesis of atherosclerosis. Also, studies indicate that vitamin D is a potent endocrine suppressor of RAAS [34]. In vitro models have shown that vitamin D suppresses renin and angiotensin gene expression, while clinical studies have found that serum concentration of vitamin $\mathrm{D}$ is inversely associated with plasma renin activity [35].

The study, which included 80 patients divided into 4 groups depending on the number of affected coronary arteries, concluded that the concentration of vitamin D, TGF- $\beta 1$ and IL-35 was negatively correlated with the severity of coronary artery disease [36].

The study that included genetic variants of VDVP $(n=1080)$ indicated that there was no association with severity of coronary disease. Also, from the same study, it was concluded that the concentration of $25(\mathrm{OH}) \mathrm{D}$ is a predictor of coronary lesions during angiography [37].

Researchers examining the association between coronary heart disease, diabetes and vitamin $\mathrm{D}$ status $(\mathrm{n}=1859$, of which $34.5 \%$ with diabetes) concluded that lower vitamin $\mathrm{D}$ concentrations in patients with diabetes were independently associated with increased prevalence and the severity of coronary artery disease [38]. Recent studies due to COVID-19 pandemia showed that decreased serum concentracion of $25(\mathrm{OH}) \mathrm{D}$ was inversely associated 
with increased serum concentracion od IL-6 and CRP, and as a conclusion increased risk of heart failure, diabetes and pneumonia [39].

\section{Recommendations for vitamin D intake}

Vitamin D deficiency in children has the greatest impact on the skeleton and leads to rickets and in adults to osteomalacia and osteoporosis. Since the production of vitamin D in the body depends on UVB radiation, residents who live at a greater distance from the equator are at higher risk of developing vitamin D deficiency. Also, people with darker skin absorb less UVB radiation, which leads to reduced vitamin $\mathrm{D}$ synthesis. Daily exposure to sunlight at a dose of one third of the minimal erythema dose is considered sufficient to produce the required amounts of vitamin D [40]. The World Health Organization states in its document on UV radiation and vitamin $\mathrm{D}$ that it is necessary to sunbathe the peripheral parts of the body for at least 5 to

Table 1. Serum concentration 25(OH)D and health

Health status
$\begin{aligned} & \text { Associated with vitamin } \mathrm{n} \\ & \text { deficiency, leads to rickets or } \\ & \text { osteomalacia }\end{aligned}$
$\begin{aligned} & \text { It is considered inadequate for } \\ & \text { maintaining the bone health of }\end{aligned}$
healthy individuals
$\begin{aligned} & \text { It is considered adequate for } \\ & \text { maintaining the bone health of } \\ & \text { healthy individuals }\end{aligned}$
$\begin{aligned} & \text { Evidence pints to potential side } \\ & \text { effects especially concentra- } \\ & \text { tions greater than } 150 \text { nmol/L } \\ & \text { or } 60 \text { ng/mL }\end{aligned}$
* Retrieved from the Institute of Medicine, Food and
Nutrition Board. Dietary Reference Intakes for Calcium
and Vitamin D. Washington, DC: National Academy
Press, 2010

\section{Vitamin D supplementation and cardiovascular risk}

Vitamin D deficiency is common, especially in developed countries, where the prevalence of vitamin $\mathrm{D}$ deficiency is from one third to one half of the adult population [4]. Also, in developed countries, there is a high prevalence of CVD and hypertension. Vitamin D deficiency is easily corrected by oral supplementation, 
which would greatly contribute to the possibility of simple and cheap intervention with the aim of reducing cardiovascular risk. Experimental evidence of an association between vitamin D metabolism and cardiovascular physiology suggests a causal relationship. However, animal models cannot reliably represent nutritional vitamin D deficiency in humans. Most existing clinical trials are designed to investigate the primary effect of supplementation on the skeleton, while the secondary effect is on the cardiovascular system.

One of the largest clinical studies is the Women's Health Initiative (WHI) with a randomized sample of $>36,000$ women, with 400 IU vitamin D supplementation and 1,000 mg daily calcium carbonate supplementation. Researchers have shown that there is no evidence that active supplementation with vitamin D and calcium carbonate leads to a reduction in the risk of coronary events or stroke (HR1.04, $95 \%$ CI 0.92 - 1.18) [44]. Also, by meta-analysis of randomized clinical trials, researchers indicated that vitamin $\mathrm{D}$ supplementation was not associated with a reduced risk of acute cardiovascular events (myocardial infarction, stroke), cardiovascular mortality. [45]. However, a large number of observational studies have shown that there is a significant bond between low serum concentration of vitamin $\mathrm{D}$ and cardiovascular events [46]. Sistematic review and meta-analysis based on the effects of vitamin D supplements on cardiovascular risk factors demonstrated that vitamin $\mathrm{D}$ supplementation (> 4,000 IU) improved serum concentrations of $25(\mathrm{OH}) \mathrm{D}$, significantly

Funding source. The authors received no specific funding for this work.

Ethical approval. This article does not contain any studies with human participants performed by any of the authors. lowered blood pressure, serum PTH, hs-CRP, TC, LDL, and TG and increased HDL. Vitamin D supplementation also appears to improve arterial stiffness [47].

\section{Conclusion}

From the time of the discovery of vitamin D until today, clinical and epidemiological studies have confirmed that vitamin D has a wide range of roles in the body in addition to those recently known roles in $\mathrm{Ca}$ and $\mathrm{P}$ homeostasis. Also, researches link vitamin D to CVD, which are at the very top of the morbidity and mortality list. Clinical evidence suggests that vitamin $\mathrm{D}$ participates in the process of atherogenesis acting anti-atherogenic, and epidemiological data speak in favor of this discovery because people with vitamin $\mathrm{D}$ deficiency have higher risk for CVD.

Namely, the scientists processed the data and came to the conclusion that the prevalence of CVD is higher in countries with fewer sunny days a year, and that the incidence of cardiovascular events is more frequent in winter when there are fewer sunny days. Based on such data, world authorities have given recommendations for daily intake of vitamin $\mathrm{D}$ as well as the recommended time of exposure to UVB rays. Since clinical trials were designed to primarily investigate the effect of vitamin D on the skeleton and secondarily on CVS, it is necessary to conduct larger number of clinical trials to investigate the role of vitamin D on the cardiovascular system.

Conflicts of interest. The authors declare no conflict of interest. 
References:

1. Gil A, Plaza-Diaz J, Mesa M, D: Vitamin D: Classic and Novel Actions. Ann Nutr Metab 2018;72:87-95.

2. Holick MF, Binkley NC, Bischoff-Ferrari HA, Gordon MC, Hanley AD, Heaney RP et al. Evaluation, treatment, and prevention of vitamin D deficiency: an Endocrine Society clinical practice guideline. J Clin Endocrinol Metab 2011;96:1911-30.

3. Schleicher RL, Sternberg MR, Lacher DA, Sempos CT, Looker AC, Durazo-Arvizu RA et al. The vitamin $\mathrm{D}$ status of the US population from 1988 to 2010 using standardized serum concentrations of 25-hydroxyvitamin D shows recent modest increases. Am J Clin Nutr 2016; 104(2):454-61.

4. Wang H, Chen W, Li D, Yin X, Zhang X, Olsen $\mathrm{N}$, Zheng SG. Vitamin D and Chronic Diseases. Aging Dis 2017;8(3):346-53.

5. Pittas AG, Dawson-Hughes B, Sheehan P, Ware $\mathrm{JH}$, Knowler WC, Aroda VR et al. Vitamin D Supplementation and Prevention of Type $2 \mathrm{Di}-$ abetes. N Engl J Med 2019;381(6):520.

6. Datta P, Philipsen PA, Olsen P, Andersen JD, Morling N, Wulf HC. Serum 25(OH)D levels after oral vitamin $\mathrm{D}_{3}$ supplementation and UVB exposure correlate. Photodermatol Photoimmunol Photomed 2019;35(5):344-53.

7. Wang T, Sun H, Ge H, Liu X, Yu F, Han H, Wang $\mathrm{J}$, Li W. Association between vitamin $\mathrm{D}$ and risk of cardiovascular disease in Chinese rural population. PLoS One 2019:23;14(5):e0217311.

8. Wang TJ, Pencina MJ, Booth SL, Jaques FP, Ingelsson E, Lanier K, et al. Vitamin D deficiency and risk of cardiovascular disease. Circulation 2008;117:503-11.

9. Anderson JL, May HT, Horne BD, Bair LT, Hall NL, Carlquist JF, et al. Relation of vitamin D deficiency to cardiovascular risk factors, disease status, and incident events in a general healthcare population. Am J Cardiol 2010;106:963-8.

10. Pavitt S, Barth JH, Cubbon RM, Kearney MT. Effects of Vitamin D on Cardiac Function in Patients With Chronic HF: The VINDICATE Study. J Am Coll Cardiol 2016:67(22):2593-603.

11. Houghton CC, Lew SQ. Long-term hypervitaminosis D-induced hypercalcemia treated with glucocorticoids and bisphosphonates. BMJ Case Report 2020:29;13(4):e233853.

12. Faridi KF, Zhao D, Martin SS, Lupton JR, Jones SR, Guallar E, et al. Serum vitamin D and change in lipid levels over $5 \mathrm{y}$ : The Atherosclerosis Risk in Communities study. Nutrition 2017;38:85-93.

13. Muscogiuri G, Annweiler C, Duval G, Karras S, Tirabassi G, Salvio G, et al. Vitamin D and cardiovascular disease: From atherosclerosis to myocardial infarction and stroke. Int J Cardiol 2017;230:577-84.

14. Kühn T, Kaaks R, Teucher B, Hirche F, Dierkes J, Weikert C, et al. Plasma 25-hydroxyvitamin $\mathrm{D}$ and its genetic determinants in relation to incident myocardial infarction and stroke in the European prospective investigation into cancer and nutrition (EPIC)-Germany study. PLoS One 2013;8(7):e69080.

15. Berghout BP, Fani L, Heshmatollah A, Koudstaal PJ, Ikram MA, Zillikens MC, Ikram MK. Vitamin D Status and Risk of Stroke: The Rotterdam Study. Stroke 2019:50(9):2293-8.

16. Dziedzic EA, Gąsior JS, Pawłowski M, Wodejko-Kucharska B, Saniewski T, Marcisz A, Dąbrowski MJ. Vitamin D level is associated with severity of coronary artery atherosclerosis and incidence of acute coronary syndromes in non-diabetic cardiac patients. Arch Med Sci 2019;15(2):359-68.

17. Sogomonian R, Alkhawam H, Jolly J, Vyas N, Ahmad S, Moradoghli Haftevani E, et al. Serum vitamin $\mathrm{D}$ levels correlate to coronary artery disease severity: a retrospective chart analysis. Expert Rev Cardiovasc Ther 2016;14(8):977-82.

18. Roth GA, Mensah GA, Johnson CO, Addolorato G, Ammirati E, Baddour LM, et al. Global Burden of Cardiovascular Diseases and Risk Factors, 1990-2019: Update From the GBD 2019 Study. J Am Coll Cardiol 2020;76(25):2982-3021.

19. Virani SS, Alonso A, Benjamin EJ, Bittencourt MS, Callaway CW, Carson AP, et al. Heart Disease and Stroke Statistics-2020 Update: A Report From the American Heart Association. Circulation 2020;141(9):e139-e596.

20. Gao Y. Vascular Endothelium. In: Gao Yuansheng, editor. Biology of Vascular Smooth 
Muscle: Vasoconstriction and Dilatation. Singapore: Springer; p. 27-40.

21. Kim DH, Meza CA, Clarke H, Kim JS, Hickner RC. Vitamin D and Endothelial Function. Nutrients 2020;12(2):575.

22. Vladimirov S, Zeljković A, Gojković T, Miljković M, Stefanović A, Zeljković D, et al. Associations of cholesterol and vitamin D metabolites with the risk for development of high grade colorectal cancer. J Med Biochem 2020:2;39(3):318-27.

23. Laird E, McNulty H, Ward M, Hoey L, McSorley E, Wallace J, et al. Vitamin D deficiency is associated with inflammation in older Irish adults. J Clin Endocrinol Metab 2014;99(5):1807-15.

24. Saheb Sharif-Askari F, Saheb Sharif-Askari N, Halwani R, Abusnana S, Hamoudi R, Sulaiman N. Low Vitamin D Serum Level Is Associated with HDL-C Dyslipidemia and Increased Serum Thrombomodulin Levels of Insulin-Resistant Individuals. Diabetes Metab Syndr Obes 2020;13:1599-607.

25. Zhou W, Yuan G, Wang Q. Vitamin D attenuates lipopolysaccharide-induced inflammatory response in endothelial cells through inhibition of PI3K/Akt/NF- $\kappa \mathrm{B}$ signaling pathway. Pharmazie 2019;74(7):412-7.

26. Helde-Frankling M, Björkhem-Bergman L. Vitamin D in Pain Management. Int J Mol Sci 2017;18(10):2170.

27. Lin L, Zhang L, Li C, Gai Z, Li Y. Vitamin D and Vitamin D Receptor: New Insights in the Treatment of Hypertension. Curr Protein Pept Sci 2019;20(10):984-95.

28. Krishna SM. Vitamin D as A Protector of Arterial Health: Potential Role in Peripheral Arterial Disease Formation. Int J Mol Sci 2019;20(19):4907.

29. Zhao TX, Mallat Z. Targeting the Immune System in Atherosclerosis: JACC State-of-the-Art Review.JAm Coll Cardiol2019;73(13):1691-706.

30. Dupuis ML, Pagano MT, Pierdominici M, Ortona $\mathrm{E}$. The role of vitamin $\mathrm{D}$ in autoimmune diseases: could sex make the difference? Biol Sex Differ 2021;12(1):12.

31. Mozos I, Stoian D, Luca CT. Crosstalk between Vitamins A, B12, D, K, C, and E Status and Arterial Stiffness. Dis Markers 2017;2017:8784971.
32. Xu S, Song J, Zhang ZH, Fu L, Gao L, Xie DD, et al. The Vitamin D status is associated with serum C-reactive protein and adhesion molecules in patients with renal cell carcinoma. Sci Rep 2019;9(1):16719.

33. Stach K, Kalsch AI, Nguyen XD, Elmas E, Kralev S, Lang S, et al. 1a,25-dihydroxyvitamin D3 attenuates platelet activation and the expression of VCAM-1 and MT1-MMP in human endothelial cells. Cardiology 2011;118:107-15.

34. Li X, Liu Y, Zheng Y, Wang P, Zhang Y. The Effect of Vitamin D Supplementation on Glycemic Control in Type 2 Diabetes Patients: A Systematic Review and Meta-Analysis. Nutrients 2018;10(3):375.

35. Giménez VMM, Sanz RL, Marón FJM, Ferder L, Manucha W. Vitamin D-RAAS Connection: An Integrative Standpoint into Cardiovascular and Neuroinflammatory Disorders. Curr Protein Pept Sci 2020;21(10):948-54.

36. Mirhosseini N, Rainsbury J, Kimball SM. Vitamin D Supplementation, Serum 25(OH)D Concentrations and Cardiovascular Disease Risk Factors: A Systematic Review and Meta-Analysis. Front Cardiovasc Med 2018;5:87.

37. Rasa F, Naderi N, Eftekhar E, Mansoori E, Rahimzadeh M. Vitamin D status in coronary artery disease: association with IL-35 and TGF- $\beta 1$ and disease severity. Endocr Metab Immune Disord Drug Targets 2018;18(5):522-9.

38. Daffara V, Verdoia M, Rolla R, Nardin M, Marino $\mathrm{P}$, Bellomo G, et al; Novara Atherosclerosis Study Group (NAS). Impact of polymorphism rs7041 and rs4588 of Vitamin D Binding Protein on the extent of coronary artery disease. Nutr Metab Cardiovasc Dis 2017;27(9):775-83.

39. Ali N. Role of vitamin D in preventing of COVID-19 infection, progression and severity. J Infect Public Health 2020;13:1373-80.

40. Nardin M, Verdoia M, Schaffer A, Barbieri L, Marino P, De Luca G; Novara Atherosclerosis Study Group (NAS). Vitamin D status, diabetes mellitus and coronary artery disease in patients undergoing coronary angiography. Atherosclerosis 2016;250:114-21.

41. Holick M.F. Sunlight, UV - radiation, vitamin D and skin cancer: how much sunlight do we need? Adv Exp Med Biol 2008;624:1-15. 
42. World Health Organization. Intersun The Global UV project. A Guide and Compendium. Geneva, 2003.

43. U.S Department of Agriculture and Haelth and Human services. Dietary Guidelines for Americans, 2020-2025. $9^{\text {th }}$ edition. 2020.

44. Institute of Medicine, Food and Nutrition Board. Dietary Reference Intakes for Calcium and Vitamin D. Washington, DC: National Academy Press, 2010.

45. Zittermann A, Pilz S. Vitamin D and Cardiovascular Disease: An Update. Anticancer Res 2019;39(9):4627-35.
46. Barbarawi M, Kheiri B, Zayed Y, Barbarawi O, Dhillon H, Swaid et al. Vitamin D Supplementation and Cardiovascular Disease Risks in More Than 83000 Individuals in 21 Randomized Clinical Trials: A Meta-analysis. JAMA Cardiol 2019;4(8):765-76.

47. Mirhosseini N, Rainsbury J, Kimball SM. Vitamin D Supplementation, Serum 25(OH)D Concentrations and Cardiovascular Disease Risk Factors: A Systematic Review and Meta-Analysis. Front Cardiovasc Med 2018;5:87.

\title{
Vitamin D i ateroskleroza
}

\author{
Vesna Lazić ${ }^{\text {, Biljana Mijović2 }}$, Miloš Maksimović3, \\ Olivera Raševićc ${ }^{4}$ Maida Mulićs ${ }^{5}$ Maja Vuković
}

'JZU Institut za javno zdravstvo Republike Srpske, Regionalni centar Zvornik, Republika Srpska, Bosna i Hercegovina

${ }^{2}$ Univerzitet Istočno Sarajevo, Medicinski fakultet Foča, Republika Srpska, Bosna i Hercegovina

${ }^{3}$ Univerzitet u Beogradu, Medicinski fakultet, Institut za higijenu sa medicinskom ekologijom, Beograd, Srbija

${ }^{4}$ Univerzitetska bolnica Foča, Republika Srpska, Bosna i Hercegovina

${ }^{5}$ Zavod za javno zdravstvo Tuzlanskog kantona, Bosna i Hercegovina

Kardiovaskularne bolesti zauzimaju prvo mesto na listi mortaliteta globalno, odnosno $31 \%$. Osnovna mera prevencije u skladu sa preporukama Svetske zdravstvene organizacije je promena rizičnih ponašanja u pogledu ishrane, fizičke aktivnosti, konzumacije duvana i alkohola. Vitamin $D$ je ranije prepoznat kao regulator odnosa kalcijuma i fosfora, remodeliranje kosti, odnosno glavni kontrolor skeletne patofiziologije. Međutim, vitamin D uživa veliko interesovanje u kliničkim i epidemiološkim istraživanjima u pogledu njegovog mogućeg uticaja na smanjenje rizika od kardiovaskularnih bolesti. Između ostalog, deficit vitamina D se dovodi u vezu sa povećanim rizikom od endotelne disfunkcije. lako je deficit identifikovan kao marker rizika za kardiovaskularne bolesti, mehanizam delovanja vitamina D na putu od endotelne disfunkcije do kardiovaskularnih bolesti nije u potpunosti otkriven. Otkrića u ovom segmentu delovanja vitamina $D$ bi bila značajna u pogledu smanjenja morbiditeta $\mathrm{i}$ mortaliteta od kardiovaskularnih bolesti.

Ključne reči: vitamin $D$, endotelna disfunkcija, ateroskleroza, kardiovaskularne bolesti, mortalitet 